Chirurgia (2018) 113: 391-398

No. 3, May - June

Copyright@ Celsius

http://dx.doi.org/10.21614/chirurgia.113.3.391

\title{
Functional Results Following Pylorus-Preserving Pancreatoduodenectomy with Pancreaticogastrostomy
}

\author{
Bogdan Filip ${ }^{1,2}$, Ionut Hutanu ${ }^{1,2}$, Ana-Maria Musina ${ }^{1,2}$, Iulian Radu ${ }^{1,2}$, Madalina Gavrilescu ${ }^{1,2}$, \\ Dragos Viorel Scripcariu ${ }^{1,2}$, Viorel Scripcariu ${ }^{1,2}$ \\ ${ }^{1} 1^{\text {st }}$ Surgical Unit, Regional Institute of Oncology lasi \\ 2Department of Surgery, University of Medicine and Pharmacy "Gr. T. Popa" lasi
}

Corresponding author:

Ionut Hutanu, MD, PhD

$1^{\text {st }}$ Oncological Surgical Unit

Regional Institute of Oncology lasi

General Henry Mathias Berthelot 2-4

lasi, Romania

E-mail: hionut65@yahoo.com
Received: 30.04 .2018

Accepted: 26.05 .2018

\section{Rezumat \\ Rezultatele funcționale după duodenopancreatectomia cefalică cu prezervare de pilor și anastomoză pancreatico-gastrică}

Introducere: Duodenopancreatectomia cu prezervare de pilor prezintă beneficii în ce priveşte durata mai scurtă a intervenției chirurgicale şi statusul nutrițional postoperator mai bun dar cu riscul apariției în postoperator a tulburărilor de evacuare gastrică. Metode: Am efectuat un studiu retrospectiv în care au fost incluşi pacienții la care s-a efectuat duodenopancreatectomie cefalică în perioada mai 2012 - mai 2018 în cadrul Clinicii I Chirurgie a Institutului Regional de Oncologie Iaşi la care au fost analizați principalii parametri postoperatori

Rezultate: $\mathrm{Au}$ fost 47 de pacienți la care s-a practicat duodenopancreatectomie cefalică; la 42 din aceştia a fost folosită tehnica cu prezervare de pilor şi anastomoză pancreatico-gastrică. Tumora a fost localizată la nivelul pancreasului cefalic ( $\mathrm{n}=21 ; 44,68 \%)$, ampulei lui Vater ( $\mathrm{n}=14 ; 29,78 \%)$, coledocului distal $(\mathrm{n}=7 ; 14,89 \%)$, duodenului ( $\mathrm{n}=2 ; 4,25 \%)$, si la nivelul colonului drept $(\mathrm{n}=3 ; 6,38 \%)$. 10 pacienți $(21,2 \%)$ au dezvoltat postoperator complicații de grad III-V în clasificarea Dindo Clavien. 12 pacienți $(25,5 \%)$ au dezvoltat postoperator fistulă pancreatică: $8(17 \%)$ pacienți cu fistulă de $\operatorname{grad}$ A, $3(6,4 \%)$ cu fistulă de grad B şi $1(2,12 \%)$ pacient cu fistulă de grad C. Tulburările de evacuare gastrică s-au întâlnit la 17 pacienți (36,17\%): grad A la $9(19,15 \%)$ pacienți, grad B la 6 pacienți $(4,5 \%)$ şi grad C la 2 pacienți $(2,25 \%)$. 3 pacienți au dezvoltat fistulă biliară postoperatorie. 4 pacienți au necesitat o relaparotomie.

Concluzii: Rezultatele studiului nostrum sunt concordante cu rezultatele din literatură şi arată că duodenopancreatectomia cu 
prezervare de pilor asociată cu anastomoza pancreatico-gastrică nu creşte riscul de tulburare de evacuare gastrică.

Cuvinte cheie: duodenopancreatectomie, morbiditate, cancer pancreatic, fistulă pancreatică, evacuare gastric întârziată

\begin{abstract}
Background: Pylorus preserving (PP) pancreaticoduodenectomy (PD) has several advantages in terms of shorter operation time and improved nutritional status but with an increased risk for delayed gastric emptying.

Methods: We performed a retrospective study on all patients in which PD was performed from May 2012 to May 2018. It was analyzed early postoperative outcomes and the incidence of delayed gastric emptying (DGE) syndrome for patients with pylorus PP PD technique and pancreaticogastrostomy (PG).

Results: There were $47 \mathrm{PD}$, in which PP technique was performed in 42 cases. The tumour location was in the pancreatic head ( $\mathrm{n}=21,44.68 \%)$, periampullary (ampulla of Vater) $(\mathrm{n}=14,29.78 \%)$, distal bile duct $(\mathrm{n}=7,14.89 \%)$, duodenum $(\mathrm{n}=2,4.25 \%)$ and advanced right colon cancer $(\mathrm{n}=3,6.38 \%)$. There were 10 cases $(21.2 \%)$ of grade III-V complications, grade A pancreatic fistula (PF) 8 cases (17\%), grade $\mathrm{B}$ in 3 cases $(6.4 \%)$ and grade $\mathrm{C}$ in 1 case (2.12\%). DGE was encountered in 17 cases $(36.17 \%)$, grade A 2 cases (4.25\%), grade B in 4 cases (8.5\%) and grade C in 2 cases (4.25\%). Biliary fistula occurred in 3 cases $(6.4 \%)$ and in 4 cases relaparotomy was needed.

Conclusions: The results of our study are concluding with the previous studies, the addition of PG to PP PD does not increase the risk of DGE.
\end{abstract}

Key words: pancreaticoduodenectomy, morbidity, pancreatic cancer, pancreatic fistula, delayed gastric emptying

\section{Background}

PD remains the single radical treatment option for patients diagnosed with malignant tumours located in the pancreatic head, periampullary region or the duodenum, in addition the procedure is performed for some benign conditions. In a limited number of cases this procedure is performed for tumours originating in surrounding organs invading the duodenum or the pancreas. Pancreatic cancer (PC) represents the fourth cause of deaths in the world (1) and the estimates are that in the next decades will become the third one (2). Pancreatic surgery remains a highly demanding surgical procedure for the surgeon, the anesthesiology team and nevertheless for the patient. Even in highly experienced centers there are postoperative morbidity rates up to $50 \%$ with a mortality rates below $5 \%$, mainly due to the standardized surgical technique and perioperative care (3).

Although it was first imagined and described by Kausch in the beginning of the $20^{\text {th }}$ century, the original technique consisted only in the resection of some portions of the duodenum and the head of the pancreas. Once with the discovery of vitamin $\mathrm{K}$, the advances in anesthesiology and of the intensive care, Allen O. Whipple refined the procedure, initially presented the first 3 cases, and in the 1946 presented his first 10 year experience of radical excision of the head of pancreas and duodenum (4).

A standard PD involves a distal gastrectomy 
with removal of the pancreatic head, duodenum and first 10 to $15 \mathrm{~cm}$ of the jejunum, common bile duct and gallbladder followed by reconstruction of gastrointestinal route. Watson was the first surgeon that modified the standard Whipple procedure by preserving the pylorus in a patient with carcinoma of the papilla of Vater. Traverso and Longmire presented the first large series of patients with chronic pancreatitis and duodenal cancer with PP technique (5). This was the moment from which a debate whether or not to preserve the pylorus was born, the advocates of this modification states that patients present an improved nutritional status, the major argument against pylorus preservation is that the pylorus plays a central role in the occurrence of a DGE due to the devascularisation and denervation that induces pylorospasm.

One of the most important debate subjects in pancreatic surgery is the treatment of the pancreatic stump. Postoperative $\mathrm{PF}$ is the most common and severe complication after pancreatic head resection and it can lead to serious consequences such as hemorrhage, sepsis, need for reintervention, prolonged hospital stay and increased mortality. Pancreticojejunostomy was preferred anasthomosis with several variations: end-to-end, end-to-side pancreticojejunalanasthomosis, either duct-tomucosa or with invagination. PG was proposed as an alternative to this technique especially in patients with soft pancreatic gland and small duct. Several randomized studies were published in order to compare the superiority of each method with conflicting results regarding the risk of mortality and PF, but the results of a meta-analysis from 2015 showed that the rate of pancreatic fistula was significantly lower in the PG $(11.2 \%$ vs. $18.7 \%$, $\mathrm{p}=0,0003)$ with the same mortality rates $(3.7 \%$ vs. $3.9 \%$ ) and lower biliary fistula rate (6).

The purpose of our study is to present the early postoperative outcomes in terms of mortality and morbidity (postoperative pancreatic fistula, septic complication) and also the functional results following a single center continuous series of patients in which $\mathrm{PD}$ was performed.

\section{Methods}

We performed a retrospective review of all patients who underwent PD in the $1^{\text {st }}$ Surgical Unit of the Regional Institute of Oncology Iasi during May 2013 and May 2018. Patients' data were recorded in a prospectively maintained database, for all the patients an informed consent for surgical procedure and data management was obtained. We included in the study patients diagnosed with pancreatic head tumours, ampullary tumours, duodenal cancer and right-sided colon tumours invading the duodenum.

Preoperative workout included clinical assessment, laboratory investigations including tumoral markers and radiological investigations (abdominal ultrasound, abdominal computed tomography, magnetic resonance cholangiopancreatography, chest X-ray). Preoperative biliary drainage was performed in a limited number of cases by endoscopic retrograde cholangiopancreatography.

Surgical technique consisted in an approach using extended right subcostal incision or a midline laparotomy based on patients characteristics or surgeon choice. In all of the cases the anterior approach was used in surgical dissection, standard regional lymphadenectomy was performed harvesting all the nodes between the hepatoduodenal ligament, right side of the superior mesenteric vessels and the inferior vena cava. Division of the pancreatic neck was performed using surgical scalpel with diathermy hemostasis on pancreatic stump surface. Transection of the duodenum is performed a centimeter distal to the pylorus. The cut end of the pancreas is mobilized from the retroperitoneal tissues for a distance of 2 to $3 \mathrm{~cm}$, which requires ligation of several vessels tributaries to splenic vein. The pancreatic duct is probed with a 5 or 6 French tube and its patency assured. The posterior surface of the stomach is freed from the posterior bursa omentalis and a serous incision is performed on the posterior face corresponding to the topography of the pancreatic stump. The two layer anastomosis is performed by placing a 4-0 polydioxanone continuous suture between the 
pancreatic capsule and the serosa of the stomach. A small incision is performed in the center of denudated area on the stomach and a duct to mucosa anastomosis is performed using the stent. A further single layer continuous suture is performed in a fashion similar with the posterior row. The cut end of the small bowel is passed through the mesocolon and a single layer duodeno-jejunostomy is performed, the biliary anastomosis is usually performed at a distance of at least $15 \mathrm{~cm}$ from the latter in a termino-lateral fashion. A feeding jejunostomy is inserted for postoperative nutritional support and a gastric tube is inserted.

Postoperative care included routinely administration of octreotide analogues, early enteral feeding using jejunostomy, continuous proton pomp inhibitors. The output of drainages and of the nasogastric tube is monitored. The nasogastric tube is removed between the $3^{\text {rd }}$ and the $5^{\text {th }}$ postoperative day, and a clear liquid diet is started.

Complications were defined as any adverse event from the normal postoperative course in the first 30 days after surgery. Major complications that required endoscopic, radiologic or surgical intervention were defined as class 3 or higher according to Clavien classification system (7). PF was defined according to the 2016 update of the International Study Group (8). Delayed gastric emptying was defind as an output of nasogastric tube greater than $500 \mathrm{ml}$ per day that persisted after the $10^{\text {th }}$ postoperative day, the failure to maintain oral intake or the reinsertion of a nasogastric tube and it was graded according actual recommendations (9).

Statistical analysis of the data was performed using MedCalc v9.2.0.1. The quantitative variables were done using mean and standard deviation, the categorical variables by way of percentages.

\section{Results}

During our study period there were 47 cases of PD (25 males and 22 females) with a mean age of 62 years. Patient's characteristics are summarized in Table 1. The most frequent tumour localization was in the pancreatic
Table 1. Patients' characteristics

\begin{tabular}{|c|c|}
\hline $\mathbf{n}$ & \\
\hline Age & $62(51-73)$ \\
\hline Gender Male/Female & $25 / 22$ \\
\hline ECOG performance status $0 / 1$ & $32 / 15$ \\
\hline Charlson Comorbidity index & $4(3-5)$ \\
\hline $\mathrm{BMl}(\mathrm{kg} / \mathrm{m} 2)$ & $27.3(21.8-32.8)$ \\
\hline Serum albumin $(\mathrm{g} / \mathrm{dl})$ & $4,26(3.83-4.69)$ \\
\hline Ca19.9 (U/ml) & $442(8.9-886)$ \\
\hline Preoperative bilirubin (mg/dl) & $6,59(5.48-7.70)$ \\
\hline Preoperative biliary drainage & $2(4,2 \%)$ \\
\hline Preoperative chemotherapy & $1(2,12 \%)$ \\
\hline \multicolumn{2}{|l|}{ Primary cancer } \\
\hline Pancreatic cancer & $21(44.68 \%)$ \\
\hline Ampullary carcinoma & $14(29.78 \%)$ \\
\hline Distal bile duct cancer & $7(14.89 \%)$ \\
\hline Duodenal cancer & $2(4.25 \%)$ \\
\hline Others & $3(6.38 \%)$ \\
\hline
\end{tabular}

head (21 cases, 44.68\%) and ampullary carcinoma (14 cases, 29.78\%). Less frequent tumour localization were: distal bile duct in 7 cases $(14.89 \%)$, duodenal cancer in 2 cases $(4.25 \%)$ and in 3 cases $(6.38 \%)$ right sided colon cancer with direct invasion of duodenum or with direct communication. There were no patients diagnosed with chronic pancreatitis. Despite the fact that most of the patients with bile duct obstruction presented elevated levels of bilirubin (mean levels $6.24 \mathrm{mg} / \mathrm{dl}$ ), preoperative stenting was performed only in 2 cases. The mean Charlson Comorbidity score

Table 2. Intraoperative findings and technique

\begin{tabular}{lc}
\hline Pylorus preserving & $42(89.36 \%)$ \\
\hline Whipple & $5(10.63 \%)$ \\
\hline Pancreatic duct stenting & $47(100 \%)$ \\
\hline Yes & 0 \\
\hline No & 1 \\
\hline Mean operating time (minutes) & $240(160-320)$ \\
\hline Mean no. of red cell units transfused & \\
intraoperative & $20(42 \%)$ \\
\hline Pancreatic consistency & $15(32 \%)$ \\
\hline Soft & $12(26 \%)$ \\
\hline Firm & $3,2(1.2-5.2)$ \\
\hline Unknown/Missing & \\
\hline Pancreatic duct diameter &
\end{tabular}


Table 3. Postoperative outcomes

\begin{tabular}{lc}
\hline Mean length of in hospital stay & $23,6(12.6-34.6)$ \\
\hline Median intensive care stay & $6(2-10)$ \\
\hline Grade III-V complications (Dindo-Clavien) & $10(21,2 \%)$ \\
\hline Pancreatic fistula & $12(25,5 \%)$ \\
\hline Biochemical leak & $8(17 \%)$ \\
\hline Grade B & $3(6,4 \%)$ \\
\hline Grade C & $1(2.12 \%)$ \\
\hline Biliary fistula & $3(6.4 \%)$ \\
\hline Delayed gastric emptying & $17(36.17 \%)$ \\
\hline Grade A & $9(19.15 \%)$ \\
\hline Grade B & $6(12.76 \%)$ \\
\hline Grade C & $2(4.25 \%)$ \\
\hline Postpancreatectomyhemorrhage $(31)$ & $8(17.02 \%)$ \\
\hline Grade A & $2(4.25 \%)$ \\
\hdashline Grade B & $4(8.5 \%)$ \\
\hdashline Grade C & $2(4.25 \%)$ \\
\hline Mean days NGT required & $5(1-9)$ \\
\hline NGT reinserted & $8(17 \%)$ \\
\hline Wound infection & $7(14,9 \%)$ \\
\hline Intra-abdominal abscess requiring reintervention & $1(2,12 \%)$ \\
\hline Other infections & $15(32 \%)$ \\
\hline Clostridium difficile infection & $9(19,15 \%)$ \\
\hdashline Cholangitis & $3(6,38 \%)$ \\
\hline Reoperation & $3(6,38 \%)$ \\
\hline In hospital mortality & $2(4,26 \%)$ \\
\hline 30 day mortality & $2(4,26 \%)$ \\
\hline
\end{tabular}

was 3.6 (standard deviation 1.2), with a mean BMI of 27.3 (SD 5.5).

In 42 cases $(89.36 \%)$ it was performed pylorus PP PD. As recorded intraoperative, the duration of surgery was 240 minutes (SD $80 \mathrm{~min}$ ), most of the patients presented a soft consistency of pancreatic parenchyma, 20 cases $(42 \%)$, with a mean pancreatic duct diameter of $3,2 \mathrm{~mm}$. intraoperative findings and technique details are presented in Table 3. In all patients a pancreatic duct stenting during the anastomosis was performed. Vascular resection was performed in two cases, a resection of portal vein, with terminoterminal anastomosis and a superior mesenteric artery resection and anastomosis.

Outcomes after surgery are summarized in Table 3. Overall severe complications following surgery occurred in 10 cases (21.2\%). PF appeared in 12 cases, most of them were grade I (biochemical leak), 8 cases (17\%), grade B in 3
$(6,4 \%)$ and grade $\mathrm{C}$ in1 case. Biliary fistula occurred in 3 cases $(6.4 \%)$, no biliary collection was encountered after surgery on abdominal imaging, and in all of those cases a conservatory treatment protocol was applied. Postoperative hemorrhage occurred in 8 cases $(17.02 \%)$, and in 2 cases it required relaparotomy for hemostasis, of those cases all patients developed PF. Abdominal septic collection that required surgical drainage was developed in one case. Other significant postoperative complications included Clostridium difficile infection in 9 cases $(19.15 \%)$ and cholangitis in 3 cases (6.38\%), of those in 2 cases a preoperative endoscopic stenting was performed.

In patients with PP technique the nasogastric tube was maintained for 5 days, delayed gastric emptying occurred in 17 cases $(36.17 \%)$, in 8 patients $(17.02 \%)$ it was necessary to reinsert the nasogastric tube, and in 2 patients a failure to tolerate oral liquids beyond the $10^{\text {th }}$ postoperative day was encountered. The last cases were patients that also presented a PF.

Overall hospital stay was 23.6 days (SD 11 days) with a median intensive care stay of 6 days. Postoperative and 30 days mortality was $4.26 \%$ ( 2 cases), one patient with superior mesenteric artery resection and anastomosis developed in the $10^{\text {th }}$ postoperative day a small bowel ischemia with necrosis and another patient developed pulmonary sepsis.

\section{Discussions}

Although the DGE is not the most severe complication following PD, it is still the most frequent one. The late onset of oral feeding in patients after PD has several short-term consequences such as prolonged hospital stay, impaired quality of life and also long-term oncological consequences, such as the delay of initiation of chemotherapy that can influence overall survival of patients with pancreatic cancer.

The main purpose of this retrospective study is to evaluate the morbidity and functional results after PD in our service. Although there was a 5-year study period, the relatively 
limited number of cases was explained by the lack of centralization of cases. All those patients represent the initial experience of a newly opened oncological surgical department. The advantages are that there is a uniform preoperative protocol, an accurate intraoperative assessment of pancreatic consistency, pancreatic duct diameter and a standardized technique for anastomosis. Furthermore, there was a unique protocol for postoperative treatment, surveillance and management of complications (same criteria for $\mathrm{PF}$, hemorrhage or delayed gastric emptying).

The PP PD has the advantages of a shorter operation time with lower blood transfusion rates, but with an increased risk for DGE. The pathogenesis of this complication seems to be multifactorial: early enteral feeding, postoperative complications, PF occurrence and reconstruction route. The presence of a postoperative complication is the most significant risk factor for DGE, this can be explained by some degree of gastro paresis due to local inflammation or an abscess formation (10). One of the most frequent complications following PD is PF that itself increases and prologues the risk of DGE (11). Furthermore, a DGE could be the early sign of a possible abdominal complication, especially $\mathrm{PF}$ formation or a fluid collection, prior to other clinical sign or abdominal drain discharge. In our series, of the 17 cases of DGE, in 12 cases a clinical significant $\mathrm{PF}$ preceded or was developed in the same time with the onset of this complication. In another case a fluid collection was demonstrated on abdominal ultrasound without signs on infection. In all the cases the evolution of PF output and the DGE syndrome had a parallel evolution, the remission of symptoms were synchronous with the drop of fistula debit.

The reconstruction method was found to be another factor associated with DGE. Antecolic reconstruction, based on the results of a metaanalysis, avoids the risk of mechanical outflow obstruction, with an increased motility of the stomach and a lower pressure on pancreatic anastomosis, and thus a reduced risk of $\mathrm{PF}$ $(11,12)$. In our study a retrocolic route was chosen for the passage of the small bowel, with a wide opening of the transverse mesocolon and without angulation of the small bowel, those were the rationale for this technique. All of the anastomosis are located in the supramesocolic region, the only possible obstacle being at the passage of the small bowel through the mesocolon.

Despite the fact that early enteral feeding provides the most physiological and functional nutrition route and it prevents the morphological alteration of the gut, this method was demonstrated to be, based on previous studies, a risk factor for postoperative complications, including DGE(13). We believe that that the advantages of early enteral feeding, especially immunonutrition surpasses the potential complications induced and that this should be demonstrated by further randomized trials. In all the patients in our series a jejunostomy feeding tube was inserted at the end of the intervention and early enteral nutrition was used.

One of the most difficult key points during PD is the treatment of the pancreatic stump. The end result is the reduction of $\mathrm{PF}$ that can itself cause serious second-degree complications, such as: sepsis, hemorrhage, wound infection, prolonged hospitalization, the need for reintervention and death. The risk factors for this complication are: the consistency of pancreas, a small pancreatic duct with a posterior localization, a decreased blood supply and surgeon experience (14). In order to give evidence based recommendations several randomized trials have been conducted in order to find the best anastomotic technique (invagination vs. duct-to-mucosa, pancreticojejunostomy vs. PG, pancreatic duct stenting, fibrin glue). Up to date there is no sufficient data to promote the superiority of either technique. There are several techniques for pancreaticojejunostomy (end-to-side, invagination, duct-to-mucosa, binding technique, using a single or double layer) (15). The results of several studies suggested that duct-to-mucosa is the safest technique in term of fistula formation (less than 20\%) (16). PG was considered to be an alternative to pancreaticojejunostomy, 
the rationale for this technique is: the lack of activation of pancreatic enzymes in the acidic gastric environment, the anatomic proximity of the two organs (less anastomotic tension) and high vascularization of the stomach wall, and also it might be technically easier to perform. Despite those advantages, the long-term consequence of this technique is the exocrine insufficiency, which can develop in up to $62 \%$ of cases (17), the predictive factors for this technique are the hard consistency of the parenchyma, duct dilatation due to anastomotic stricture and previous impaired pancreatic function $(18,19)$. Currently there a 9 randomized trials published that investigated the superiority of each anastomosis. In 5 trials there were no statistical significant differences regarding the incidence of $\mathrm{PF}(20-24)$, the other 4 trials showed lower rates of fistulas following PG (25-27). Due to the lack of homogeneity between those studies there were published 17 meta-analysis. In one of the recent one, that included 1121 patients, the incidence of $\mathrm{PF}$ is lower after PG $(11.2 \%$ vs. $18.7 \%$; OR 0.53 , $\mathrm{p}=0.0003$ ) (6). In our series the use of pancreaticojejunostomy was based on experience with acceptable morbidity rates and the rationale for this type of anastomosis were enounced previously. We believe that the anatomic proximity of the two organs and the rich vascularization of the stomach are the two main reasons in order to perform this type of anastomosis.

In our series preoperative biliary stenting was limited to two cases due to the lack of this maneuver in the first 3 years of our study, and it was limited to patients with severe cholestasis and impaired liver functional tests. Both patients developed cholangitis prior to surgery that required antibiotics. Preoperative biliary stenting has the role of improving liver function, nutritional status and cell mediated immunity (28). Although the intention is to reduce postoperative morbidity, this procedure was demonstrated to prolong the duration of surgery, to increase the risk of sepsis and overall higher postoperative complication rates (29). Current recommendations are that preoperative stenting should be avoided and restricted to patients with cholangitis and elevated bilirubin levels, and if the surgery can be performed within a week the drainage should be avoided (30).

There are major drawbacks of our study: it is not a comparative study, the number of cases in which pancreaticojejunostomy was used is lower in order to perform adequate statistical analysis andthe relatively lower number of cases limits. The advantages are that is a continuous series of patients, the same surgical technique with the same postoperative protocol.

\section{Conclusion}

Currently, all over the world there is a large heterogeneity regarding the extent of resection (with or without distal gastric resection) and the reconstruction method and yet no best practice has emerged as the ideal surgical technique. Moreover, there is no standardization regarding the use of stent, somatostatin analogues and other means to reduce PF. The most common sense rule is that the performance and the refinement of a single technique can lead to lesser rates of complications.

\section{Conflict of interest}

The authors declare no conflicts of interests.

\section{Refrences}

1. Siegel RL, Miller KD, Jemal A. Cancer Statistics, 2017. CA Cancer J Clin. 2017;67(1):7-30.

2. Rahib L, Smith BD, Aizenberg R, Rosenzweig AB, Fleshman JM, Matrisian LM. Projecting cancer incidence and deaths to 2030: the unexpected burden of thyroid, liver, and pancreas cancers in the United States. Cancer Res. 2014;74(11):2913-21.

3. Harnoss JC, Ulrich AB, Harnoss JM, Diener MK, Buchler MW, Welsch T. Use and results of consensus definitions in pancreatic surgery: a systematic review. Surgery. 2014;155(1):47-57.

4. Whipple AO, Parsons WB, Mullins CR. Treatment of Carcinoma of the Ampulla of Vater. Ann Surg. 1935;102(4):763-79.

5. Traverso LW, Longmire WP, Jr. Preservation of the pylorus in pancreaticoduodenectomy. Surg Gynecol Obstet. 1978;146(6):959-62.

6. Menahem B, Guittet L, Mulliri A, Alves A, Lubrano J. Pancreaticogastrostomy is superior to pancreaticojejunostomy for prevention of pancreatic fistula after pancreaticoduodenectomy: an updated meta-analysis of randomized controlled trials. Ann Surg. 2015; 261(5):882-7.

7. Dindo D, Demartines N, Clavien PA. Classification of surgical complications: a new proposal with evaluation in a cohort of 6336 patients and results of a survey. Ann Surg. 2004;240(2):205-13.

8. Bassi C, Marchegiani G, Dervenis C, Sarr M, Abu Hilal M, Adham 
M, et al. The 2016 update of the International Study Group (ISGPS) definition and grading of postoperative pancreatic fistula: 11 Years After. Surgery. 2017;161(3):584-91.

9. Wente MN, Bassi C, Dervenis C, Fingerhut A, Gouma DJ, Izbicki JR, et al. Delayed gastric emptying (DGE) after pancreatic surgery: a suggested definition by the International Study Group of Pancreatic Surgery (ISGPS). Surgery. 2007;142(5):761-8.

10. Riediger H, Makowiec F, Schareck WD, Hopt UT, Adam U. Delayed gastric emptying after pylorus-preserving pancreatoduodenectomy is strongly related to other postoperative complications. J Gastrointest Surg. 2003;7(6):758-65.

11. Qu H, Sun GR, Zhou SQ, He QS. Clinical risk factors of delayed gastric emptying in patients after pancreaticoduodenectomy: a systematic review and meta-analysis. Eur J Surg Oncol. 2013;39(3):213-23.

12. Kurahara $H$, Shinchi $H$, Maemura K, Mataki $Y$, lino S, Sakoda M, et al. Delayed gastric emptying after pancreatoduodenectomy. J Surg Res. 2011;171(2):e187-92.

13. Martignoni ME, Friess H, Sell F, Ricken L, Shrikhande S, Kulli C, et al. Enteral nutrition prolongs delayed gastric emptying in patients after Whipple resection. Am J Surg. 2000;180(1):18-23.

14. Gouma DJ, van Geenen RC, van Gulik TM, de Haan RJ, de Wit LT, Busch OR, et al. Rates of complications and death after pancreaticoduodenectomy: risk factors and the impact of hospital volume. Ann Surg. 2000;232(6):786-95.

15. Berger AC, Howard TJ, Kennedy EP, Sauter PK, Bower-Cherry M, Dutkevitch $S$, et al. Does type of pancreaticojejunostomy after pancreaticoduodenectomy decrease rate of pancreatic fistula? A randomized, prospective, dual-institution trial. J Am Coll Surg. 2009;208(5):738-47; discussion 47-9.

16. Bai X, Zhang Q, Gao S, Lou J, Li G, Zhang Y, et al. Duct-to-Mucosa vs Invagination for Pancreaticojejunostomy after Pancreaticoduodenectomy: A Prospective, Randomized Controlled Trial from a Single Surgeon. J Am Coll Surg. 2016;222(1):10-8.

17. Casadei R, Ricci C, Silvestri S, Campra D, Ercolani G, D'Ambra M, et al. Peng's binding pancreaticojejunostomy after pancreaticoduodenectomy. An Italian, prospective, dual-institution study. Pancreatology. 2013;13(3):305-9.

18. Nakamura H, Murakami Y, Uemura K, Hayashidani Y, Sudo T, Ohge $\mathrm{H}$, et al. Predictive factors for exocrine pancreatic insufficiency after pancreatoduodenectomy with pancreaticogastrostomy. J Gastrointest Surg. 2009;13(7):1321-7

19. Hirono S, Murakami Y, Tani M, Kawai M, Okada K, Uemura K, et al. Identification of risk factors for pancreatic exocrine insufficiency after pancreaticoduodenectomy using a 13C-labeled mixed triglyceride breath test. World J Surg. 2015;39(2):516-25.

20. Yeo CJ, Cameron JL, Maher MM, Sauter PK, Zahurak ML, Talamini $\mathrm{MA}$, et al. A prospective randomized trial of pancreaticogastrostomy versus pancreaticojejunostomy after pancreaticoduodenectomy. Ann Surg. 1995;222(4):580-8; discussion 8-92.

21. Bassi C, Falconi M, Molinari E, Salvia R, Butturini G, Sartori N, et al. Reconstruction by pancreaticojejunostomy versus pancreaticogastrostomy following pancreatectomy: results of a comparative study. Ann Surg. 2005;242(6):767-71, discussion 71-3.

22. Duffas JP, Suc B, Msika S, Fourtanier G, Muscari F, Hay JM, et al. A controlled randomized multicenter trial of pancreatogastrostomy or pancreatojejunostomy after pancreatoduodenectomy. Am J Surg. 2005;189(6):720-9.

23. Wellner UF, Sick O, Olschewski M, Adam U, Hopt UT, Keck T. Randomized controlled single-center trial comparing pancreatogastrostomy versus pancreaticojejunostomy after partial pancreatoduodenectomy. J Gastrointest Surg. 2012;16(9):1686-95.

24. Keck T, Wellner UF, Bahra M, Klein F, Sick O, Niedergethmann M, et al. Pancreatogastrostomy Versus Pancreatojejunostomy for RECOnstruction After PANCreatoduodenectomy (RECOPANC, DRKS 00000767): Perioperative and Long-term Results of a Multicenter Randomized Controlled Trial. Ann Surg. 2016;263(3): 440-9.

25. Fernandez-Cruz L, Cosa R, Blanco L, Lopez-Boado MA, Astudillo E. Pancreatogastrostomy with gastric partition after pyloruspreserving pancreatoduodenectomy versus conventional pancreatojejunostomy: a prospective randomized study. Ann Surg. 2008; 248(6):930-8

26. Topal B, Fieuws S, Aerts R, Weerts J, Feryn T, Roeyen G, et al. Pancreaticojejunostomy versus pancreaticogastrostomy reconstruction after pancreaticoduodenectomy for pancreatic or periampullary tumours: a multicentre randomised trial. Lancet Oncol. 2013;14(7):655-62.

27. Figueras J, Sabater L, Planellas P, Munoz-Forner E, Lopez-Ben S, Falgueras $\mathrm{L}$, et al. Randomized clinical trial of pancreaticogastrostomy versus pancreaticojejunostomy on the rate and severity of pancreatic fistula after pancreaticoduodenectomy. Br J Surg. 2013; 100(12):1597-605.

28. Sewnath ME, Karsten TM, Prins MH, Rauws EJ, Obertop H, Gouma DJ. A meta-analysis on the efficacy of preoperative biliary drainage for tumors causing obstructive jaundice. Ann Surg. 2002;236(1):17-27.

29. van der Gaag NA, Rauws EA, van Eijck $\mathrm{CH}$, Bruno MJ, van der Harst $\mathrm{E}$, Kubben FJ, et al. Preoperative biliary drainage for cancer of the head of the pancreas. N Engl J Med. 2010;362(2):129-37.

30. Lutz MP, Zalcberg JR, Ducreux M, Aust D, Bruno MJ, Buchler MW, et al. 3rd St. Gallen EORTC Gastrointestinal Cancer Conference: Consensus recommendations on controversial issues in the primary treatment of pancreatic cancer. Eur J Cancer. 2017;79:41-9.

31. Wente MN, Veit JA, Bassi C, Dervenis C, Fingerhut A, Gouma DJ, et al. Postpancreatectomy hemorrhage (PPH): an International Study Group of Pancreatic Surgery (ISGPS) definition. Surgery. 2007; 142(1):20-5. 